\title{
Sodium butyrate in post-hatch feed for broiler chicks
}

[Uso de butirato de sódio em rações pós-eclosão para pintos de corte]

\author{
F.B. Carvalho ${ }^{1}$, J.H. Stringhini ${ }^{1}$, M.B. Café ${ }^{1}$, R.M. Jardim Filho ${ }^{2}$, \\ P.H.S. Paz ${ }^{3}$, B.M. Santos ${ }^{4}$ \\ ${ }^{1}$ Universidade Federal de Goiás - Goiânia, GO \\ ${ }^{2}$ São Salvador Alimentos - Itaberaí, GO \\ ${ }^{3}$ Hubbard SAS - France \\ ${ }^{4}$ Faculdade União de Goyazes - Trindade, GO
}

\begin{abstract}
This study was designed to determine adequate levels for sodium butyrate inclusion in pre-hatching and pre-starter feed in order to minimize the negative effects of post-hatch delayed placement on broiler chicks. Newly-hatched chicks were allotted in a completely randomized design, with five treatments, each comprising five replicates of ten birds each. Five dietetic levels of sodium butyrate (control, 0.050, 0.075, 0.100 and $0.200 \%$ ) were used in the pre-starter feed offered to the chicks in the transporting box and during the pre-starter phase. Performance, yolk sac retraction, plasma glucose concentration, weight and histomorphometry of the small intestine were evaluated after 24 hours of feed access and at 7 days of age. A metabolic trial was performed when the chicks were seven to ten days of age. Supplementation of $0.1 \%$ sodium butyrate increased the development of broiler chicks' intestinal villi at seven days of age but was not able to improve performance in the pre-starter phase. Supplementation with sodium butyrate in a diet offered in the transportation box does not improve broiler performance in the pre-starter phase. Supplementation of up to $0.16 \%$ is recommended, in order to improve the metabolizability of the ether extract for broilers at seven days of age.
\end{abstract}

Keywords: delayed placement, glucose, histomorphometry, organic acid, poultry

\section{RESUMO}

Objetivou-se, com este estudo, encontrar níveis adequados de inclusão de butirato de sódio em ração pós-eclosão e pré-inicial, buscando minimizar os efeitos negativos do jejum de pintos de corte. Os animais foram distribuídos em delineamento inteiramente ao acaso, com cinco tratamentos e cinco repetições de 10 aves cada. Foram utilizadas cinco suplementações de butirato de sódio (controle; 0,05; 0,075; 0,100 e 0,200\%) na ração pré-inicial, fornecidas aos pintos na caixa de transporte e durante a fase pré-inicial. Após 24 horas de acesso ao alimento e aos sete dias de idade, foram avaliados desempenho, retração do saco vitelino, concentração de glicose plasmática, peso e histomorfometria do intestino delgado. De sete a 10 dias de idade, realizou-se ensaio de metabolizabilidade. A suplementação de 0,10\% de butirato de sódio aumentou o desenvolvimento das vilosidades intestinais dos pintos de corte aos sete dias de idade, mas não foi capaz de melhorar o desempenho na fase pré-inicial. A suplementação com butirato de sódio em dieta oferecida na caixa de transporte não melhora o desempenho dos frangos na fase pré-inicial. Recomenda-se suplementação de até 0,16\%, a fim de melhorar a metabolizabilidade do extrato etéreo para frangos de corte aos sete dias de idade.

Palavras-chave: ácido orgânico, frango, glicose, histomorfometria, jejum, saco vitelino

Recebido em 20 de abril de 2020

Aceito em 1 de dezembro de 2020

E-mail: fabyolab@hotmail.com 


\section{INTRODUCTION}

The post-hatch period is a critical time for broiler chicks. It allows adaptation of the chick to the environment outside the egg and, especially, improves feed digestion and absorption for nutrients coming from exogenous sources. Long fasting times between hatching and allocation to the poultry house add difficulty to this period that chicks undergo.

Because of standard incubator procedures, chicks do not have access to feed for a period of approximately 48 hours, from their hatching until their placement. This could mean that they do not have access to feed for two or three days (Bhuiyan et al., 2011). The reserves contained in the yolk sac are the first sources of nutrients used by the fasting chick. The reserves present in the yolk sac are quickly consumed during the first 48 hours after hatching, which is why some research shows that chicks are able to recover when fasting is not as long and their performance is not impaired (Carvalho et al., 2013). Delayed posthatch feeding of 24-hour was not detrimental to the performance of male and female broilers, but 36 hours reduced feed intake and final weight at 42 days for the females (Shinde Tamboli et al., 2018). Delayed intake of feed can hinder their physiological and immunological development, thus reducing the overall productivity of chickrearing (Van Den Brand et al., 2010).

Specific formulas are recommended for the posthatch and pre-starter phase diets of broiler chicks. These formulas include the presence of trophic agents that can attenuate the effects of post-hatch delayed placement, in order to increase precocity in the physical and physiological development of broiler chicks. Butyric acid is a short-chain organic acid that is recognized as the main energy source for the intestinal mucosa of cecal and colon epithelial cells. Colonocytes can metabolize small amounts of propionate and acetate, whereas butyrate can contribute about $70 \%$ of the total energy consumed by these cells (Stevens and Hume, 1998).

Therefore, there are several mechanisms that can explain the contribution of butyric acid towards increased nutrient digestibility. These mechanisms can involve any of the following: reducing intestinal $\mathrm{pH}$; increasing the solubility of the ingredients; increasing cell proliferation and production through trophic effects on the mucosa (Chamba et al., 2014); or, simply through antimicrobial effects, controlling pathogenic microorganisms and favoring beneficial ones (Wu et al., 2018). In a recent review on the effect of sodium butyrate on the intestinal health of poultry, conducted by Elnesr et al. (2020), it was found that sodium butyrate plays an important role in maintaining the integrity of the intestinal mucosa, as shown by improvement of intestinal histomorphometry. Use of sodium butyrate improved the intestinal microbial community. The objective of the present study was to ascertain the appropriate levels of sodium butyrate inclusion in post-hatch and pre-starter feed, from the perspectives of minimizing the negative effects of post-hatch delayed placement and ensuring intestinal integrity and nutritional support for these chicks.

\section{MATERIALS AND METHODS}

This research on animals was conducted in accordance with our institution's committee on animal use, under protocol no. 008/13. The treatments consisted of five levels of sodium butyrate supplementation: control (no supplementation), $0.050, \quad 0.075, \quad 0.100$ and $0.200 \%$ of commercial product. These represented $0,115,173,230$ and 460grams of sodium butyrate inclusion per ton of pre-starter feed. The product was added as replacement for starch in the baseline pre-starter feed (Table 1), which was formulated with corn and soybean meal, following the Rostagno et al. (2011) nutritional recommendations.

A total of 1,200 male Cobb 500 chicks were used. These originated from eggs produced by breeder hens of the same age (60 weeks), which were incubated in the same machine. The chicks were removed from the hatchery. They were vaccinated and sexed, following the standard procedures of the hatchery, and then they were transported to the poultry shed. All the procedures conducted on the chicks, from hatching until housing, took a total of 24 hours. The birds were distributed in the transportation boxes in a completely randomized design consisting of five treatments, with five replicates of 60 birds each. During this 24-hour period, the chicks received $3 \mathrm{~g} / \mathrm{bird}$ of pre-starter feed, and did not receive water, in order to simulate what happens in the hatchery. 


\section{Carvalho et al.}

Table 1. Composition and values calculated (\%) for the baseline diet

\begin{tabular}{|c|c|}
\hline \multirow[b]{2}{*}{ Ingredients } & Pre-starter feed \\
\hline & 1 to 7 days \\
\hline Corn & 51.06 \\
\hline Soybean meal & 39.50 \\
\hline Soybean oil & 2.35 \\
\hline Calcitic limestone & 0.88 \\
\hline Dicalcium phosphate & 1.94 \\
\hline L-lysine & 0.20 \\
\hline DL-methionine & 0.25 \\
\hline Threonine & 0.10 \\
\hline Sodium bicarbonate & 0.19 \\
\hline Table salt & 0.39 \\
\hline Vitamin supplement ${ }^{1}$ & 0.10 \\
\hline Mineral supplement ${ }^{2}$ & 0.05 \\
\hline Starch & 3.00 \\
\hline Total & 100.00 \\
\hline \multicolumn{2}{|c|}{ Calculated Composition } \\
\hline Metabolizable energy (kcal/kg) & $2,951.00$ \\
\hline Crude protein $(\%)$ & 22.280 \\
\hline Calcium $(\%)$ & 0.922 \\
\hline Available phosphorus (\%) & 0.471 \\
\hline Methionine (\%) & 0.542 \\
\hline Methionine + cystine $(\%)$ & 0.850 \\
\hline Lysine $(\%)$ & 1.312 \\
\hline Threonine $(\%)$ & 0.852 \\
\hline Sodium $(\%)$ & 0.223 \\
\hline Chlorine $(\%)$ & 0.283 \\
\hline \multicolumn{2}{|c|}{$\begin{array}{l}{ }^{1} \text { Vitamin supplement - guaranteed levels per kilogram of product: } 3,125,000 \mathrm{IU} \text { of vitamin A; } 550,000 \mathrm{IU} \text { of vitamin } \\
\text { D3; 3,750mg of vitamin E; } 625 \mathrm{mg} \text { of vitamin K3; } 250 \mathrm{mg} \text { of vitamin B1; } 1,125 \mathrm{mg} \text { of vitamin B2; } 250 \mathrm{mg} \text { of vitamin } \\
\text { B6; 3,750mg of vitamin B12; } 9,500 \mathrm{mg} \text { of niacin; } 3,750 \mathrm{mg} \text { of calcium pantothenate; } 125 \mathrm{mg} \text { of folic acid; } 350,000 \mathrm{mg} \\
\text { of DL-methionine; } 150,000 \mathrm{mg} \text { of choline chloride } 50 \% ; 50 \mathrm{mg} \text { of selenium; } 2,500 \mathrm{mg} \text { of antioxidant; and } 1,000 \mathrm{~g} \text { of } \\
\text { vehicle q.s.p. }{ }^{2} \text { Mineral supplement -guaranteed levels per kilogram of product: manganese, } 150,000 \mathrm{mg} \text {; zinc, } \\
\text { 100,000mg; iron 100,000mg; copper, } 16,000 \mathrm{mg} \text {; and iodine, } 1,500 \mathrm{mg} \text {. }\end{array}$} \\
\hline
\end{tabular}

After 24 hours of experimental feed consumption, 10 chicks per replicate $(50$ chicks per treatment), according to the average batch weight, were transferred to galvanized steel cages equipped with linear feeders and water dispensers. The chicks continued to receive the same experimental feeds in the cages until they reached seven days of age. Water and feed were offered ad libitum over the whole rearing period, continuous lighting, 24 hours per day. The maximum and minimum environmental temperatures were monitored twice a day (8:00 $\mathrm{AM}$ and 5:00 PM), using thermometers within the shed. The mean maximum and minimum temperatures during the experiment were $33.47^{\circ} \mathrm{C}$, and $25.48^{\circ} \mathrm{C}$, respectively.

After 24 hours in the transportation box, five chicks per treatment were chosen at random. To evaluate the effect of the experimental feed, their body weight, yolk sac weight and intestinal weight were measured; fragments were collected from the duodenum, jejunum and ileum, and glucose concentration was measured. The rest of the chicks were housed in the batteries in accordance with the treatments. At seven days of age, five broilers per treatment were separated for evaluation. Again, body weight, yolk sac weight and intestinal weight were measured; fragments were collected from the duodenum, jejunum and ileum, and glucose concentration was measured.

Weight gain was calculated as the difference between the final and initial weights. Feed intake was calculated as the difference between the feed supplied and the leftovers at the end of each phase. Feed conversion was obtained through the 
ratio of feed consumption/weight gain. Livability was assessed through the formula $\mathrm{V}(\%)=100-$ mortality. Glucose concentration was assessed through analysis within thirty seconds after drawing blood, using portable glucose metering equipment (Accu-Chek Active; Roche ${ }^{\circledR}$ ). Five birds from each treatment were euthanized to evaluate intestinal development and yolk sac retraction. The yolk sac and intestines (small and large) were then weighed on a scale with precision of $0.0001 \mathrm{~g}$.

One chick per replicate was sampled for histomorphometry measurements of the small intestine. Two-centimeter fragments were collected from the duodenum, jejunum and ileum, and these were fixed in buffered $10 \%$ formaldehyde for 24 hours. These samples were then subjected to standard histological procedures to produce histological slides. The sections were stained with hematoxylin and eosin (Hu et al., 2012; Sousa et al., 2015). The heights of 10 villi and the depths of 10 crypts were measured on each section.

A metabolic trial was conducted when the chicks were between seven and 10 days of age, using the total excreta collection method. Excreta were collected twice a day (8:00 AM and 5:00 PM), stored in plastic bags (which were identified according to the replicate) and kept in a freezer. At the end of the experimental period, the amount of feed consumed, and excreta produced were determined. The samples of excreta and experimental feed were used to determine the dry matter, nitrogen and ether extract content, as described by Silva and Queiroz (2002).
The results from the bromatological analyses were used to calculate coefficients of metabolizability (MC) for dry matter (MCDM), nitrogen (MCN) and ether extract (MCEE). Nitrogen balance (NB) and ether extract balance (EEB) were also calculated as described by Sakomura and Rostagno (2007). All the data analyses were evaluated for normality of distribution, using the Shapiro-Wilk test. Polynomial regression analysis was performed in relation to the sodium butyrate concentrations tested $(\mathrm{P}<0.05)$.

\section{RESULTS AND DISCUSSION}

Before the chicks were placed in the transportation box, 15 chicks were separated as controls and data on their average body weight (44.54g), average yolk sac weight (5.87g), average intestinal weight $(1.87 \mathrm{~g})$ and blood glucose level $(348.2 \mathrm{mg} / \mathrm{dL})$ were collected. Descriptive presentation of the values of the live weights of the chicks before and 24 hours after the experimental ration, and the amounts of feed consumed for a better understanding of the subsequent results (Table 2). The values showed that the chicks consumed little amount of feed and, therefore, presented an average weight loss of $2.49 \mathrm{~g}$ during the period of 24 hours inside the transport boxes. The reduction in live weight of the chicks during this phase occurred due to higher use of energy reserves from the yolk sac, digestive and renal excretions, and dehydration (Leu et al., 2002; Carvalho et al., 2013). The treatments in this experiment were not sufficient to reduce these effects.

Table 2. Mean weight loss and feed intake of pre-starter diet supplemented with sodium butyrate, for newly hatched chicks, before and after a 24-hour waiting period in transportation boxes

\begin{tabular}{lcccc}
\hline \multicolumn{1}{c}{ Treatment } & Weight before $(\mathrm{g})$ & $\begin{array}{c}\text { Weight after } 24 \\
\text { hours }(\mathrm{g})\end{array}$ & Weight loss $(\mathrm{g})$ & $\begin{array}{c}\text { Feed } \\
\text { consumption }(\mathrm{g})\end{array}$ \\
\hline Control & 45.45 & 42.90 & 2.55 & 0.009 \\
$0.050 \%$ & 45.49 & 42.90 & 2.59 & 0.017 \\
$0.075 \%$ & 45.53 & 43.08 & 2.45 & 0.012 \\
$0.100 \%$ & 46.58 & 43.31 & 3.27 & 0.018 \\
$0.200 \%$ & 46.13 & 44.36 & 1.76 & 0.032 \\
Mean & 45.53 & 43.28 & 2.49 & 0.024 \\
\hline
\end{tabular}

The live weight of the chicks, retraction of the yolk sac, small intestine weight and glucose levels (Table 3) were not affected by butyrate supplementation, probably due to the low feed intake in the transportation box. Different results were observed by Bhanja et al. (2009), who found that there was greater reduction of yolk sacs in chicks that were fed immediately after hatching, thus suggesting that feed intake might increase the mechanical activity of the intestine, 
such that the yolk sac would be absorbed more rapidly.

Fasting chicks go through a critical gluconeogenic metabolism period, with increases in ketosis and dehydration. If feed is supplied quickly, these effects might be minimized, through alteration of the glycemic pattern of these birds (Vieira and Moran, 1999). Gluconeogenesis decreases as the plasma glucose concentrations increase through feed consumption. Our results showed that chickens are relatively hyperglycemic, compared with mammals. Hyperglycemia is independent of feed intake. In the experiment conducted by Zhao et al. (2014), the authors observed blood concentrations greater than $200 \mathrm{mg} / \mathrm{dL}$ at hatching (before feed intake).

Table 4 presents the results regarding the development of intestinal villi in the chicks that were fed a pre-starter diet supplemented with sodium butyrate. Butyrate supplementation linearly influenced crypt depth in the jejunum (P $=0.004)$ and ileum $(\mathrm{P}=0.009)(\mathrm{Y}=33.5133+$ 0.0621970X; $\left.\quad \mathrm{R}^{2}=0.61\right)$. As butyrate supplementation increased, greater jejunum crypt depth was obtained. A quadratic effect was observed in relation to the ileum $(\mathrm{Y}=32.5688+$ $0.2563317 \mathrm{X}-0.913753 \mathrm{X}^{2} ; \mathrm{R}^{2}=0.96$ ), with a maximum point at butyrate supplementation of $0.140 \%$ in the chick feed. Increasing crypt depth implies greater rates of cell proliferation and renovation of intestinal epithelium, thereby increasing the number of villi, since these structures originate from the lower part of the crypt (Fernandes et al., 2017). The literature shows that in 6-week-old broilers, the three largest groups of bacteria detected in the ileum and cecum through molecular analyses were Lactobacillus sp., Enterococcus cecorum and butyrate-producing bacteria (Van Den Brand et al., 2010).

Table 3. Evaluation of yolk sac retraction, intestinal weight and blood glucose of chicks that were fed a pre-starter diet supplemented with sodium butyrate, after a 24-hour waiting period in transportation boxes

\begin{tabular}{lcccc}
\hline \multicolumn{1}{c}{ Treatment } & Weight $(\mathrm{g})$ & Yolk sac $(\mathrm{g})$ & Intestine $(\mathrm{g})$ & Glucose $\mathrm{mg} / \mathrm{dL}$ \\
\hline Control & 43.20 & 3.97 & 2.31 & 296.00 \\
$0.050 \%$ & 43.62 & 3.22 & 2.33 & 336.60 \\
$0.075 \%$ & 43.26 & 4.05 & 2.51 & 223.00 \\
$0.100 \%$ & 43.36 & 3.80 & 2.65 & 337.60 \\
$0.200 \%$ & 43.63 & 3.87 & 2.41 & 350.80 \\
P-value & 0.998 & 0.881 & 0.778 & 0.788 \\
${ }^{1}$ CV & 6.05 & 35.77 & 19.54 & 18.05 \\
\hline
\end{tabular}

* Polynomial regression $(\mathrm{P}<0.05) .{ }^{1}$ Coefficient of variation.

Table 4. Evaluation of villi development, villi height, crypt depth and villus/crypt ratio $(\mu \mathrm{m})$ in the intestines of chicks that were fed a pre-starter diet supplemented with sodium butyrate, after a 24-hour waiting period in transportation boxes

\begin{tabular}{lccccccccc}
\hline \multicolumn{3}{c}{ Duodenum } & \multicolumn{3}{c}{ Jejunum } & \multicolumn{3}{c}{ Ileum } \\
\hline & Crypts & Villi & V/C & Crypts & Villi & V/C & Crypts & Villi & V/C \\
\hline Control & 35 & 256 & 7.19 & 37 & 179 & 4.86 & 33 & 164 & 4.95 \\
$0.050 \%$ & 40 & 133 & 3.32 & 31 & 167 & 5.28 & 41 & 163 & 3.96 \\
$0.075 \%$ & 36 & 207 & 5.79 & 37 & 148 & 4.00 & 46 & 179 & 3.93 \\
$0.100 \%$ & 41 & 219 & 5.35 & 41 & 138 & 3.35 & 51 & 178 & 3.52 \\
$0.200 \%$ & 47 & 224 & 4.80 & 47 & 162 & 3.45 & 47 & 142 & 3.02 \\
P-value & 0.147 & 0.309 & 0.201 & $0.004 *$ & 0.655 & 0.100 & $0.009 *$ & 0.183 & $0.021^{*}$ \\
${ }^{1}$ CV & 13.94 & 15.35 & 15.03 & 9.41 & 21.97 & 21.80 & 10.85 & 11.28 & 14.66 \\
\hline
\end{tabular}

* Polynomial regression $(\mathrm{P}<0.05) .{ }^{1}$ Coefficient of variation.

The villus/crypt ratio of the ileum decreased linearly with increasing butyrate supplementation. The normal process of cell renewal occurs through two associated primary cytological events: cell renewal (proliferation and differentiation), resulting from splits in totipotent cells located in the crypt and along the villi; and loss by scaling occurring at the apex of the villi. The villus/crypt ratio indicates the balance of these two processes (Uni et al., 2003). Although the result from the current work meant that the chicks had lower nutrient absorption 
capacity, this did not affect the final weight at 7 days of life (Table 5).

The performance results from the pre-starter phase are presented in Table 5. Butyrate supplementation did not improve chick performance until seven days of age. The reserves contained in the yolk sac are the first sources of nutrients used by the fasting chick.
The reserves present in the yolk sac are quickly consumed during the first 48 hours after hatching, so some research shows that the chicks are able to recover when the fast is not as long (Carvalho et al., 2013) as in the case of the current research that provided a 24-hour fast, which showed no detrimental effect on performance at seven days of age.

Table 5. Performance in the pre-starter phase (1 to 7 days) among chicks that were fed diets supplemented with sodium butyrate

\begin{tabular}{lcccccc}
\hline Treatment & $\begin{array}{c}\text { Initial } \\
\text { weight }(\mathrm{g})\end{array}$ & $\begin{array}{c}\text { Final } \\
\text { weight } \\
(\mathrm{g})\end{array}$ & $\begin{array}{c}\text { 1Weightgain } \\
(\mathrm{g})\end{array}$ & $\begin{array}{c}\text { Daily weight } \\
\text { gain }(\mathrm{g})\end{array}$ & $\begin{array}{c}\text { Consumption } \\
(\mathrm{g})\end{array}$ & $\begin{array}{c}\text { Feed } \\
\text { conversion } \\
(\mathrm{g} / \mathrm{g})\end{array}$ \\
\hline Control & 43.02 & 187.07 & 144.05 & 20.57 & 168.14 & 1.075 \\
$0.050 \%$ & 43.00 & 186.22 & 143.42 & 20.48 & 171.03 & 1.094 \\
$0.075 \%$ & 43.08 & 183.34 & 140.25 & 20.03 & 171.49 & 1.121 \\
$0.100 \%$ & 43.32 & 187.24 & 143.92 & 20.56 & 170.99 & 1.089 \\
$0.200 \%$ & 43.67 & 192.02 & 147.55 & 21.14 & 176.64 & 1.094 \\
P-value & 0.274 & 0.428 & 0.550 & 0.550 & 0.246 & 0.261 \\
${ }^{C}$ CV & 1.24 & 3.73 & 4.83 & 4.83 & 3.30 & 2.89 \\
\hline
\end{tabular}

* Polynomial regression $(\mathrm{P}<0.05) .{ }^{2}$ Coefficient of variation.

Previous reports had indicated that butyrate or its sodium salt (sodium butyrate) had beneficial effects on growth performance of broilers in terms of increased feed intake coupled with body weight gain and significantly improved feed conversion (Chamba et al., 2014; Antongiovanni et al., 2007). Panda et al. (2009) also supplemented the broiler diet with $0.2,0.4$ and $0.6 \%$ butyrate at 42 days of age, and observed that the weight gain of broilers that were fed the control diet was similar to that of treatment with the $0.2 \%$ butyrate diet. However, weight gain and feed conversion were better using treatments with 0.4 and $0.6 \%$ butyric acid than using other treatments, including a positive control with antibiotic growth promoters.

The current experiment evaluated only the prestarter phase. A considerable amount of butyrate may therefore be preferentially applied by enterocytes to stimulate intestinal development and function in chicks rather than to improve growth performance during the starter period. Sodium butyrate supplementation did not influence the retraction of the yolk sac, the absolute intestinal weight or the plasma glucose levels at seven days of age (Table 6). Regardless of the treatments, the results showed that the intestine weight increased during the first week post-hatch, whereas yolk sac weight decreased rapidly, which were indicative of maturation of digestive and glucose regulatory functions. Contrary to the current experiment, GonzálezOrtiz et al. (2019) supplemented broilers' feed with sodium butyrate ( $1 \mathrm{~kg} /$ ton) at 21 days of age and observed that these birds presented greater weight of the duodenum, jejunum and total intestine. However, this weight did not improve the broilers' performance.

There was no statistical difference in butyrate concentration in relation to the variables of villus height, crypt depth and villus/crypt ratio of the duodenum when the chicks reached seven days of age (Table 7). Butyrate supplementation influenced jejunum villus height, presenting a quadratic effect $(P=0.029)$ with a maximum point at supplementation of $0.09 \%$ ( $\mathrm{Y}=303.121$ $\left.+0.929697 \mathrm{X}-5.13939 \mathrm{X}^{2} ; \mathrm{R}^{2}=0.59\right)$. This demonstrated that an improvement in jejunum villus development was achieved with $0.1 \%$ butyrate supplementation. Butyrate is readily absorbed by enterocytes as a source of energy for accelerating intestinal development and function, as well as for overall health (Van Immerseel et al., 2004). Long villi and deep crypts are generally thought to support a larger surface area for higher absorption capacity and healthy development of the intestine, but they also support greater tissue turnover, thereby accounting for the optimal status of the gut (Olukosi and Dono, 2014). 
Table 6. Evaluation of yolk sac retraction and intestinal growth among chicks that were given pre-starter feed supplemented with sodium butyrate, at the age of seven days

\begin{tabular}{lccc}
\hline Treatment & Yolk sac $(\mathrm{g})$ & ${ }^{1}$ Intestinal weight $(\mathrm{g})$ & Glucose $(\mathrm{mg} / \mathrm{dL})$ \\
\hline Control & 0.45 & 15.68 & 338.25 \\
$0.050 \%$ & 0.30 & 15.21 & 336.40 \\
$0.075 \%$ & 0.23 & 14.78 & 327.60 \\
$0.100 \%$ & 0.37 & 16.58 & 333.80 \\
$0.200 \%$ & 0.21 & 16.57 & 349.80 \\
P-value & 0.771 & 0.455 & 0.802 \\
${ }^{2}$ CV & 32.28 & 11.13 & 8.46 \\
\hline
\end{tabular}

${ }^{1}$ Weight of the small and large intestines; ${ }^{2}$ Coefficient of variation.

Table 7. Evaluation of villi development, villi height, crypt depth and villus/crypt ratio $(\mu \mathrm{m})$ in the intestines of chicks that were fed a pre-starter diet supplemented with sodium butyrate at seven days of age

\begin{tabular}{|c|c|c|c|c|c|c|}
\hline & \multicolumn{3}{|c|}{ Duodenum } & \multicolumn{3}{|c|}{ Jejunum } \\
\hline & Crypts $^{1}$ & Villi $^{1}$ & $\mathrm{~V} / \mathrm{C}^{1}$ & Crypts $^{1}$ & Villi ${ }^{1}$ & $\mathrm{~V} / \mathrm{C}^{1}$ \\
\hline Control & 62 & 454 & 7.36 & 60 & 314 & 5.20 \\
\hline $0.050 \%$ & 50 & 425 & 8.43 & 71 & 314 & 4.43 \\
\hline $0.075 \%$ & 69 & 529 & 7.62 & 60 & 326 & 5.45 \\
\hline $0.100 \%$ & 58 & 485 & 8.31 & 67 & 378 & 5.64 \\
\hline $0.200 \%$ & 58 & 451 & 7.83 & 60 & 279 & 4.62 \\
\hline P-value & 0.620 & 0.470 & 0.826 & 0.354 & $0.029 *$ & 0.208 \\
\hline${ }^{2} \mathrm{CV}$ & 8.30 & 14.99 & 16.27 & 6.64 & 9.39 & 13.38 \\
\hline
\end{tabular}

Studies on broilers at 42 days of age showed different results from this experiment. Antongiovanni et al. (2007) and Sayrafi et al. (2011) supplemented broilers with butyric acid and evaluated the morphology of the small intestine wall. They found smaller villi and larger crypt depths in the jejunum and ileum. Results from Gunal et al. (2006) and Leeson et al. (2005) demonstrated that addition of organic acid with the presence of butyric acid in broiler diets was ineffective in improving villus height. Research conducted on 21-day-old broilers showed that dietary supplementation with sodium butyrate had little relationship with crypt depth, villus height or villus/crypt ratio of the jejunum and ileum. However, addition of sodium butyrate significantly stimulated increased numbers of goblet cells on jejunal and ileal villi, such that a medium dose $(800 \mathrm{mg} / \mathrm{kg})$ was most effective (Wu et al, 2018). The results from the metabolic trial demonstrated that there were no differences in butyrate concentrations, except for ether extract metabolizability coefficient (Table 8), which was improved until reaching supplementation of $0.163 \%$.

Table 8. Nitrogen balance (NB), ether extract balance (EEB), nitrogen metabolizability coefficient (NMC), ether extract metabolizability coefficient (EEMC) and dry matter metabolizability coefficient (DMMC) of chicks that were fed a pre-starter diet supplemented with sodium butyrate, from seven to ten days of age

\begin{tabular}{lccccc}
\hline & NB $(\mathrm{g})$ & EEB $(\mathrm{g})$ & NMC $(\%)$ & EEMC $(\%)$ & DMMC $(\%)$ \\
\hline Control & 18.47 & 54.67 & 62.42 & 86.86 & 73.60 \\
$0.050 \%$ & 18.74 & 61.81 & 64.22 & 90.89 & 76.00 \\
$0.075 \%$ & 19.23 & 64.92 & 62.94 & 90.62 & 76.28 \\
$0.100 \%$ & 17.40 & 59.85 & 60.35 & 93.63 & 76.10 \\
$0.200 \%$ & 18.74 & 63.21 & 62.55 & 93.81 & 76.94 \\
*P-value & 0.830 & 0.195 & 0.510 & $0.003^{2}$ & 0.162 \\
${ }^{1}$ CV & 10.58 & 8.24 & 4.12 & 1.89 & 2.04 \\
\hline
\end{tabular}

Polynomial regression $(\mathrm{P}<0.05)$. ${ }^{1}$ Coefficient of variation. ${ }^{3} \mathrm{Y}=85.9490+101.3321 \mathrm{X}-309.2210 \mathrm{X}^{2} ; \mathrm{R}^{2}=0.70$; maximum peak at: $0.163 \%$ 
Sodium butyrate is one of the main energy sources for the intestinal mucosa of the cecum and colon (Stevens and Hume, 1998). In the present experiment, there was an improvement in the height of the jejunum villi of chicks that were fed diets containing sodium butyrate. This occurred probably due to this ability to supply the energy needs of the intestinal mucosa and to contribute to the development of enterocytes, thus improving the absorption of nutrients. Consequently, in the current work, an improvement in the metabolizability coefficient of the ether extract was obtained.

\section{CONCLUSIONS}

Supplementation with sodium butyrate in a diet offered in the transportation box does not improve broiler performance in the pre-starter phase. Supplementation of up to $0.16 \%$ is recommended, in order to improve the metabolizability of the ether extract for broilers at seven days of age.

\section{REFERENCES}

ANTONGIOVANNI, M.; BUCCIONI, A.; PETACCHI, F. et al. Butyric acid glycerides in the diet of broiler chickens: effects on gut histology and carcass composition. Ital. J. Anim. Sci., v.6, p.19-25, 2007.

BHANJA, S.K.; DEVI, C.A.; PANDA, A.K.; SUNDER, G.S. Effect of post hatch feed deprivation on yolk-sac utilization and performance of young broiler chickens. AsianAustralas. J Anim. Sci., v.2, p.1174-1179, 2009.

BHUIYAN, M.M.; GAO, F.; CHEE, S.H.; IJI, P.A. Minimising weight loss in new broiler hatchlings through early feeding of simple sugars. Anim. Poult. Sci., v.51, p.1002-1007, 2011.

CARVALHO, L.S.S.; MACHADO, C.A.; FAGUNDES, N.S. et al. Biometric development and performance of broilers submitted to different periods of post-hatching fasting. Braz. J. Vet. Res. Anim. Sci., v.50, p.300-306, 2013.

CHAMBA, F.; PUYALTO, M.; ORTIZ, A. et al. Effect of partially protected sodium butyrate on performance, digestive organs, intestinal villi and e. coli development in broilers chickens. Int. J. Poult. Sci., v.13, p.390-396, 2014.
ELNESR, S.S.; ALAGAWANY, M.; ELWAN, H.A.M. et al. Effect of sodium butyrate on intestinal health of poultry - a review. Ann. Anim. Sci., v.20, p.29-41, 2020.

FERNANDES, J.I.M.; RORIG, A.; GOTTARDO, E.T. et al. Post-hatch diets supplemented with sources of fat and added taurine and glycine on the intestinal morphology and performance of broilers at 1 to 21 days. Arq. Bras. Med. Vet. Zootec., v.69, p.198-204, 2017.

GONZÁLEZ-ORTIZ， G.; SANTOS， T.T.; VIENOLA, K. et al. Response of broiler chickens to xylanase and butyrate supplementation. Poult. Sci., v.98, p.3914-3925, 2019.

GUNAL, M.; YAYLI, G.; KAYA, O. et al. The effect of antibiotic growth promoter, probiotic or organic acid supplementation on performance, intestinal microflora and tissue of broilers. Int. J. Poult. Sci., v.5, p.149-155, 2006.

HU, C.H.; GU, L.Y.; LUAN, Z.S. et al. Effects of montmorillonite-zinc oxide hybrid on performance, diarrhea, intestinal permeability and morphology of weanling pigs. Anim. Feed Sci. Technol., v.177, p.108-115, 2012.

LEESON, S.; NAMKUNG, H.; ANTONGIOVANNI, M.; LEE, E.H. Effect of butyric acid on the performance and carcass yield of broiler chickens. Poult. Sci., v.84, p.1418-1422, 2005.

LEU, W.M.K.; COTTA, J.T.B.; OLIVEIRA, A.I.G.; RODRIGUES, P.B. Desempenho de frangos submetidos à restrição alimentar na fase inicial em diferentes sistemas de criação. Ciênc. Agrotec., v.26, p.610-617, 2002.

OLUKOSI, O.A.; DONO, N.D. Modification of digesta $\mathrm{pH}$ and intestinal morphology with the use of benzoic acid or phytobiotics and the effects on broiler chicken growth performance and energy and nutrient utilization. J. Anim. Sci., v.92, p.3945-3953, 2014.

PANDA, A.K.; RAMA RAO S.V.; RAJU, M.V.L.N.; SHYAM SUNDER, G. Effect of butyric acid on performance, gastrointestinal tract health and carcass characteristics in broiler chickens. Asian-australas. J. Anim. Sci., v.22, p.1026-1031, 2009. 
ROSTAGNO, H.S.; ALBINO, L.F.T.; DONZELE, J.L. et al. Brazilian tables for poultry and swine: composition of feedstuffs and nutritional requirements. 3.ed. Viçosa: UFV, 2011. 186p.

SAKOMURA, N.K.; ROSTAGNO, H.S. Métodos de pesquisa em nutrição de monogástricos. Jaboticabal: FUNEP, 2007. 283p.

SAYRAFI, R.; SOLTANALINEJAD, F.; SHAHROOZ, R.; RAHIMI, S. Comparative study of the effect of alternative and antibiotic feed additives on the performance and intestinal histomorphometrical parameters of broiler chickens. Afr. J. Agric. Res., v.6, p.2794-2799, 2011.

SHINDE TAMBOLI, A.S.; AKSHATGO, E.L.; MANISH, M. et al. Delayed post-hatch feeding affects the performance and immunocompetence differently in male and female broiler chickens. J. Appl. Anim. Res., v.46, p.306-313, 2018.

SILVA, D.J.; QUEIROZ, A.C. Análise de alimentos: métodos químicos e biológicos. 3.ed. Viçosa: UFV, 2002. 235p.

SOUSA, D.C.; OLIVEIRA, N.L.A.; SANTOS, E.T. et al. Morphological characterization of the gastrointestinal tract of Cobb 500® broilers. Pesqui. Vet. Bras., v.35, p.61-68, 2015.

STEVENS, C.E.; HUME, I.D. Contributions of microbes in vertebrate gastrointestinal tract to production and conservation of nutrients. Physiol. Rev., v.78, p.393-425, 1998.
UNI, Z.; TAKO, E.; GAL-GARBER, O.; SKLAN, D. Morphological, molecular and functional changes in the chicken small intestine of the late-term embryo. Poult. Sci., v.82, p.1747-1754, 2003.

VAN DEN BRAND, H.L.; MOLENAAR, R.; VAN DER STAR, I.; MEIJERHOF, R. Early feeding affects resistance against cold exposure in young broiler chickens. Poult. Sci., v.89, p.716-720, 2010.

VAN IMMERSEEL, F.; FIEVEZ, V.; DE BUCK, J. et al. Microencapsulated short-chain fatty acids in feed modify colonization and invasion early after infection with salmonella enteritidis in young chickens. Poult. Sci., v.83, p.69-74, 2004.

VIEIRA, S.L.; MORAN, E.T. Effect of egg origin and chick post-hatch nutrition on broiler live performance and meat yields. Worlds Poult. Sci. J., v.56, p.125-142, 1999.

WU, W.; XIAO, Z.; AN, W. et al. Dietary sodium butyrate improves intestinal development and function by modulating the microbial community in broilers. PLoS One, v.13, p.1-21, 2018.

ZHAO, X.; SUMNERS, L.H.; GILBERT, E.R. et al. Delayed feeding after hatch caused compensatory increases in blood glucose concentration in fed chicks from low but not high body weight lines. Poult. Sci., v.93, p.617-624, 2014. 